\title{
Regional differences in Korean children's development of speech production
}

\author{
Moonja Shin ${ }^{1} \cdot$ Ji-Wan $\mathrm{Ha}^{2, *} \cdot$ Young Tae $\mathrm{Kim}^{3} \cdot$ Soo-Jin Kim ${ }^{4}$ \\ ${ }^{1}$ Department of Speech-Language Pathology, Chosun University, Gwangju, Korea \\ ${ }^{2}$ Department of Speech Pathology, Daegu University, Gyeongsan, Korea \\ ${ }^{3}$ Department of Communication Disorders, Ewha Womans University, Seoul, Korea \\ ${ }^{4}$ Department of Communication Disorders, Korea Nazarene University, Cheonan, Korea
}

\begin{abstract}
This study aimed to investigate regional differences in the development of speech production in Korean children. A total of 619 children aged 2 to 7 years from the Jeolla, Seoul/Gyeonggi, Chungcheong, and Gyeongsang areas were included in this study. The subjects were assessed with the UTAP2 word-level test. In PWC, PMLU, and PWP, the performance was significantly lower in Gyeongsang at 2 years 11 months and in Jeolla and Chungcheong at 3 years 5 months than in Seoul/Gyeonggi. The total PCC of Gyeongsang and Chungcheong and UTAP PCC of Chungcheong were significantly lower at 2 years 11 months compared with those of Seoul/Gyeonggi, while Jeolla and Chungcheong showed significantly lower total PCC and UTAP PCC than Seoul/Gyeonggi at 3 years 5 months. However, no regional difference was observed in any indicators after the age of 3 years 6 months. These results suggest that there are regional differences in the ability to produce speech sounds at a very young age, and that the differences can be explained by the differences between Seoul/Gyeonggi and the other provinces rather than by the individual characteristics of specific regions.
\end{abstract}

Keywords: speech development, regional differences in Korea, UTAP2

\section{1. 서론}

우리나라 아동의 말소리 발달은 조음방법의 경우 비음, 파열 음, 파찰음, 유음, 마찰음 순으로 발달된다(Kim, 1996; Oum, 1986). 또한 학자마다 약간의 차이는 있으나 임상 현장에서 일 반적으로 적용되고 있는 음소발달 단계(Kim \& Shin, 2015)에 근
거할 때, /프, ㅁ, 이는 2;0-2;11세를, /ㅂ, 버, 뜨, ㅌ/는 3;0-3;11 세를, /ㄴ, 77, ㄷ/는 4;0-4;11세를, /ᄀ, ㄱ, ㅈ, 지/는 5;0-5;11세 를, / 시는 6;0-6;11세를 완전습득 연령단계로 보고 있다. 이때 완전습득 연령단계란 해당 연령의 아동 중 $95 \%-100 \%$ 가 습득한 단계를 말하며, 각 말소리는 문맥에 따라 발달에 다소 차이가 있을 수 있다. 우리말과 음운체계가 다른 영어권의 경우도 발달

\footnotetext{
*jw-ha@daegu.ac.kr, Corresponding author

Received 31 July 2019; Revised 9 September 2019; Accepted 9 September 2019

(c) Copyright 2019 Korean Society of Speech Sciences. This is an Open-Access article distributed under the terms of the Creative Commons Attribution NonCommercial License (http://creativecommons.org/licenses/by-nc/4.0) which permits unrestricted non-commercial use, distribution, and reproduction in any medium, provided the original work is properly cited.
} 
순서는 매우 비슷한 양상을 보인다. 예를 들어 Dodd et al.(2003) 의 영국 및 호주 아동 연구와 Smit et al.(1990)의 미국 아동 연구 에서 3 세에 비교적 단순하고 쉬운 소리인 양순음, 파열음, 비음 등이 먼저 발달하고, 상대적으로 복합하고 어려운 소리인 마찰 음과 유음이 후에 발달하는 것으로 보고되었다.

우리 말소리 발달을 좀 더 자세히 살펴보면, 가장 늦게 발달 하는 마찰음과 유음은 5 세 이후에야 완전 습득이 이루어진다 (Heo \& Shin, 2016). 특히 치경마찰음은 습득기간이 가장 길고, 말소리장애 집단에서 가장 대치가 많은 말소리 중 하나이다 (Cheon \& Lee, 1999). / ㅅ/, / 씨의 습득연령에 대해 Oum(1986)은 5 세까지 75\%의 습득기준에 도달하지 못하는 것으로, $\operatorname{Kim}(1996)$ 은 2-3세에 출현하지만 완전 습득 연령은 6-7세로, Cheon \& Lee(1999)는 / 시의 경우 6;6-6;11에, / 씨의 경우 7;0-7;5에 75\% 의 습득기준에 도달하는 것으로 보고하였다. 이처럼 치경마찰 음의 경우 5 세 이후에도 점진적으로 발달하는 것을 알 수 있으 며, 초기에는 생략 혹은 성문마찰음으로 대치되다가 이후 /ㄷ/ 계열이나/ㅈ/계열의 소리로 대치되고, 최종적으로 치간마찰음 등의 왜곡과정을 거쳐 점진적으로 완성된다(Kim et al., 2012).

유음 /리 또한 후기에 습득되는 말소리로, 마찬가지로 말소 리장애 아동들이 가장 많이 오류를 보이는 음소 중 하나이다. 유음/르는 초성, 특히 어중초성에서 실현되는 탄설음 $/ \mathrm{r} /$ 과 종 성에서 실현되는 설측음 $/ 1$ 로 구분할 수 있는데, 탄설음보다 설 측음이 먼저 발달한다(Kim, 1996). Choi \& Kim(2013)은 설측음 은 4세 초반에, 탄설음은 4세 후반에 안정기에 들어간다고 보고 하였다. 음운환경에 따른/리의 발달 순서는 어말, 모음 앞, 모 음 사이, 반모음 앞 순으로 알려져 있다.

이러한 연구들에서 말소리를 분석하는 방법은 말소리 단위 에 따라 분절음 평가와 단어단위 평가로 구분할 수 있다. 전자 의 대표적 지표는 자음정확도(percentage of consonants correct, $\mathrm{PCC}$ )이고, 후자의 분석방법으로는 단어단위 정확률(proportion of whole-word correctness, PWC), 평균음운길이(phonological mean length of utterance, PMLU), 단어단위 근접률(proportion of whole-word proximity, PWP) 등을 들 수 있다(Park \& Yoon, 2016). 최근 초기 음운습득이 분절음 차원이 아닌 통단어 단위 로 이루어진다는 이론이 널리 받아들여지고 있는 만큼(Kim, 2012; Yoon et al., 2013), 분절음뿐 아니라 단어단위에 대해서도 말소리 발달 능력을 살펴보는 것이 타당할 것이다(Shin \& Lee, 2015).

단어단위 음운분석에 대한 선행연구들을 좀 더 자세히 살펴 보면 다음과 같다. Seok(2006)은 단어단위 접근법에 의한 3-5세 아동의 음운특성을 분석하였으며, 그 결과 $3,4,5$ 세 연령별로 PWC는 0.70, 0.81, 0.97, PMLU는 7.24, 8.34, 10.55, PWP는 0.78, $0.91,0.98$ 이라고 보고하였다. 3 가지 단어단위 측정치는 연령 간 유의미한 차이가 있는 것으로 나타났고, 각 측정 유형 간, 특히 PWC와 PWP간 상관이 매우 높은 것으로 나타났다. Seok(2006)은 단어단위의 음운분석의 경우 그 결과를 성인의 수행력과 비교하 는 것이 용이하여, 음소적 접근보다 아동의 말소리산출 능력을 정확히 파악할 수 있다고 언급하였다. 또한 Yoon et al.(2013) 의 연
구에서는 2 세 초반, 2 세 후반, 3 세 초반, 3 세 후반, 4 세 초반의 연 령 각각에서 $\mathrm{PMLU}$ 는 $6.87,7.75,8.31,8.45,8.52$ 로, $\mathrm{PWP}$ 는 0.86, $0.89,0.92,0.97,0.98$ 로 나타났으며, 이 중 2세 후반과 3 세 초반, 2 세 후반과 3 세 후반 간 통계적 유의성이 있는 것으로 보고하였다.

앞에서 살펴보았듯이 아동의 말소리산출 능력은 연령에 의 해 많은 영향을 받는다. 그러나 말소리 발달에 영향을 미치는 요인은 비단 연령만은 아닐 것이다. 말소리에 대한 아동의 지각 과 조음능력, 심리 및 신체적 발달 등도 말소리 발달과 연관이 있을 수 있다. Owens(2012)는 서로 관련 있는 신체발달, 인지발 달, 사회정서적 발달과 소통적 성장을 언급하였는데, 이 가운데 말소리 발달은 아동이 속한 환경에 의해 많은 영향을 받는다고 하였다.

언어치료 임상에서는 아동의 말소리 발달에 대한 기준이 매 우 중요하며, 이때 발달에 영향을 미치는 요인들 역시 고려해야 한다. 말소리 발달에 영향을 미치는 변인으로는 나이, 성별, 지 능, 부모의 사회 · 경제적 위치(socioeconomic status, SES), 언어 발달 등을 들 수 있다. 국내 선행연구들은 주로 나이, 성별, 지능, 언어 발달이 말소리 발달에 미치는 영향에 대해 살펴보았다. 그 러나 부모의 학력, 직업, 살고 있는 거주지 등으로 평가되는 사 회 - 경제적 위치(SES)가 말소리 발달에 미치는 영향에 관한 연 구들은 제한적이다. 국내외 선행연구들을 종합해볼 때, 사회·경 제적 위치(SES)와 아동의 발음 발달 사이에는 상관관계가 낮거 나 혹은 거의 없는 것으로 보인다(Oum, 1986). 그렇지만 이 연구 들은 부모의 학력, 직업, 수입, 거주지 등을 구분하지 않은 채 포 괄적으로 연구를 진행한 것으로, 해당 연구들에 근거하여 거주 지가 아동의 말소리 발달에 영향을 미치지 않는다고 단정 지을 수는 없다.

지역 방언(regional dialect)의 특성에 따라 다르게 실현되는 말 소리들을 찾아볼 수 있다. 그 예로 경상도 방언의 / 시와 / 씨의 변별이 지역 방언과 관련하여 가장 많이 거론된다. 선행연구에 따르면 경남지역의 낙동강 오른쪽에 위치한 밀양, 울산, 양산, 창녕, 김해, 등에서는/ㅅ/와/씨가 변별되지 않아/시만 존재하 는 반면, 낙동강 왼쪽에 위치한 '거창, 합천, 함양, 통영, 거제' 등 에서는/시와 / 씨가 변별되어 각각의 음소로 존재한다(Kim, 1991; Kim, 2014). 따라서 '쌀, 쏜다, 싸다, 등의 단어에 대해 낙 동강 오른쪽 지역에서는/씨를 발음하지 못하고, 낙동강 왼쪽 지역에서는 / 시와 / 씨 둘 다에 대해 발음이 가능하다. 이 외에 도 부산, 전남, 강릉 지역 등 특정 지역을 제한시켜 그 지역의 방 언을 분석하는 연구들을 찾아볼 수 있다. 최근 $\operatorname{Jang}$ (2013)은 20 대와 50 대를 대상으로 대구 방언의 / ㅅ/, / ㅆ/의 실현 양상을 비 교하였다. 그 결과 대구 지역 50대 화자들은/시와/씨를 변별 하여 사용하지 못하였으나, 20 대 화자들은 서울 화자들과 마찬 가지로 두 음소를 명확하게 변별하여 사용하였다. 이러한 결과 는 세대 즉, 연령 또한 방언의 실현 양상에 영향을 미치는 요소 임을 시사한다.

따라서 지역적 차이가 아동의 말소리 발달에도 영향을 미칠 가능성을 생각해 볼 수 있다. 만일 그러하다면, 지역에 따라 미 세하게 다를 수 있는 말소리 발달 특성들은 평가 시 반드시 고 
려되어야 할 요인일 것이다. 이와 같은 이유로 Davis \& Bedore (2011)은 방언의 차이를 말소리장애와 구별하는 것이 매우 중요 하다고 언급한 바 있다. 지역 방언의 차이 또는 다중언어 환경 으로 인해 말소리 산출에 차이를 보인다면, 해당 아동을 언어치 료 대상에 포함해야 하는지에 대해서는 표준어를 사용하는 아 동 또는 단일언어 아동과는 다른 기준이 적용되어야 할 것이다. 다시 말해 말소리 발달은 지역 등과 같은 요소에 영향을 받을 수 있고, 따라서 조음평가 시 이에 대한 고려가 요구된다(Lee \& Choi, 2015). 그러나 이러한 판단의 근거가 될 수 있는, 지역별 말 소리 발달의 차이에 대한 객관적 자료와 기준은 현재 부족한 실 정이다. Lee \& Choi(2015)의 연구에서도 대구지역 유치원생을 대상으로 어휘 및 조음발달을 살펴보는 것으로 그쳤으며, 다른 지역 아동들과의 차이점을 구체적으로 제시하지는 못하였다.

따라서 본 연구에서는 아동의 말소리 발달이 지역별로 차이 를 보이는지를 알아보고자 하였다. 이를 위해 전라, 서울경기, 충청, 경상 지역의 아동들을 대상으로 다양한 말소리산출 지표 에 대해 지역 간 비교를 실시하였다. 본 연구결과 지역별 말소 리 발달의 차이가 확인된다면, 표준화된 말소리 검사의 규준자 료 이용 시 이에 대한 고려가 반드시 필요할 것이다.

\section{2. 연구 방법}

\section{1. 연구 대상}

본 연구는 UTAP2(Urimal Test of Articulation and Phonology 2) 표준화 과정에 참여한 아동을 대상으로 실시하였다. 2세 후반 부터 7세까지의 아동이 참여하였으며, 특히 2세 후반에서 4세 는 6 개월 단위로 구분하였다. 지역별 말소리 발달의 차이를 살 펴보기 위해 전라, 서울경기, 충청, 경상 지역에 거주하는 아동 을 대상으로 하였으며, 수용·표현어휘력검사(REVT) 결과 수용 어휘력이 -2SD 이상인 아동, 보호자의 동의를 받고 어린이집, 유치원 및 학교에 다니는 아동들을 대상으로 선정하였다. 본 연 구에 참여한 아동은 총 619명으로, $\mathrm{Kim}$ et al.(2018)과 $\mathrm{Ha}$ et al.(2019)의 대상자들과 동일하다. 지역, 연령 및 성별 분포는 표 1,2 와 같다.

표 1. 지역별 참여자 인원

Table 1. Number of participants by region

\begin{tabular}{c|c}
\hline Region & N (\%) \\
\hline Jeolla (JL) & $159(25.65)$ \\
\hline Seoul / Gyeonggi (SG) & $165(26.77)$ \\
\hline Chungcheong (CC) & $149(24.03)$ \\
\hline Gyeongsang (GS) & $146(23.55)$ \\
\hline Total & $619(100)$ \\
\hline
\end{tabular}

표 2. 참여자 연령 및 성별 분포

Table 2. Age and gender of participants

\begin{tabular}{c|c|c|c}
\hline Age $(\mathrm{yr} ; \mathrm{mo})$ & Male & Female & Total \\
\hline $2 ; 6-2 ; 11$ & 33 & 32 & 65 \\
\hline $3 ; 0-3 ; 5$ & 28 & 33 & 61 \\
\hline $3 ; 6-3 ; 11$ & 29 & 32 & 61 \\
\hline $4 ; 0-4 ; 5$ & 38 & 43 & 81 \\
\hline $4 ; 6-4 ; 11$ & 37 & 35 & 72 \\
\hline $5 ; 0-5 ; 11$ & 60 & 74 & 134 \\
\hline $6 ; 0-6 ; 11$ & 46 & 47 & 93 \\
\hline $7 ; 0-7 ; 11$ & 26 & 26 & 52 \\
\hline Total & 297 & 322 & 619 \\
\hline
\end{tabular}

\section{2. 연구 도구}

$\mathrm{UTAP} 2$ 의 단어수준 검사에서 단어단위 분석 지표인 PWC, $\mathrm{PMLU}, \mathrm{PWP}$ 와 분절음 차원의 분석 지표인 Total PCC, UTAP $\mathrm{PCC}$ 를 분석하였다. UTAP 2 단어수준 검사는 음절 내 어두초성, 어중초성, 어중종성, 어말종성의 4 개의 위치에서 우리말 19 개 자음과 7 개의 단모음을 타당하게 평가할 수 있는 단어 30 개로 구성되어 있다(Kim et al., 2018).

\section{3. 검사 방법}

$\mathrm{UTAP} 2$ 의 단어수준 검사는 U-TAP과 마찬가지로 그림을 제 공한 다음 아동이 자발적으로 그림의 이름을 명명하는 이름대 기 과제방식으로 진행되었으며, 아동이 자발적으로 이름을 명 명하는 데에 어려움을 보일 경우, 의미적 단서를 제공하여 명명 하도록 유도하였다(Kim \& Shin, 2004). 의미단서 제공 후에도 명명하는 데에 어려움을 보일 경우, 모델링을 제공하여 따라 말 하도록 하였다.

검사는 언어병리학을 전공하고 있는 대학원생 및 연구 실시 과정에 대해 훈련을 받은 학부생에 의해 진행되었고, 아동이 다 니는 어린이집, 유치원에서 진행하였으며 일부 아동은 가정을 직접 방문하여 검사를 실시하였다. 검사는 1 회 방문을 통해 실 시되었다.

\section{4. 자료 평가}

검사의 모든 항목에 대한 아동의 반응을 전사하여 전산화 자 동분석 프로그램(KSAT)에 입력한 후 $\mathrm{PCC}$ 와 단어단위지표들을 분석하였다.

2.4.1. 단어단위 정확률(Proportion of Whole-word Correctness, PWC) 단어단위 정확률(PWC)은 아동의 단어에 오류가 있는지 여부 를 알아보기 위해 측정되며 성인의 표준 발음 전사와 완전히 일 치한 것을 정반응으로 간주하여 기록한다.

$$
P W C=\text { 정확하게 산출한 단어 수전체 단어 수 }
$$

2.4.2. 단어단위 복잡률(Phonological Mean Length of Utterance, PMLU, 평균음운길이)

단어단위 복잡률(PMLU)은 아동이 산출한 단어의 복잡성에 
대한 정보 및 아동이 발음한 형태와 목표 형태 사이의 관계에 대한 정보를 분석하기 위해 측정된다. 자음과 모음에 대해 각 1 점 씩을 부여한 후, 정조음한 자음에 대해서는 추가로 1점을 제공한 다. 이때 부적절하게 첨가된 분절음에는 점수를 부여하지 않고, 모 음의 경우 정확하게 산출하였더라도 추가점수를 제공하지 않는다.

2.4.3. 단어단위 근접률(Proportion of Whole-word Proximity, PWP) 단어단위 근접률(PWP)은 성인의 표준 발음을 목표로 하여 아동의 단어가 얼마나 근접했는가를 분석하기 위해 측정된다.

\section{$P W P=$ 아동의 $P M L U /$ 목표발화 $P M L U$}

\subsection{4. 전체 자음정확도(Total PCC)와 UTAP 자음정확도(UTAP PCC)}

$\mathrm{PCC}$ 는 자음을 정확하게 발음한 백분율이다. Total PCC는 $\mathrm{UTAP}$ 단어수준 검사의 전체 자음에 대해 $\mathrm{PCC}$ 를 계산한 값이 고, UTAP PCC는 UTAP2 단어수준 검사에서 미리 주어진 48개 의 자음에 대해 $\mathrm{PCC}$ 를 계산한 값이다.

$$
P C C=\text { 정조음한 자음수조음해야 할 총 자음수 } \times 100
$$

\section{5. 타당도 분석}

UTAP2의 타당도를 검증하기 위해 Kim et al.(2018)은 내용타 당도와 구인타당도, 그리고 공인타당도를 분석하였다. 단어검 사에 사용된 30 개 단어와 문장검사에서 사용한 총 11 개 문장에 대한 준거 질문을 통한 내용타당도에서 5 점 척도로 측정한 결 과, 전체 평균이 단어수준와, 문장수준에서의 타당한 정도가 '약간 그렇다'의 수준을 보인 것으로 보고되었다. 또한 구인타 당도는 2-5세 집단에서 문장 PMLU를 제외한 모든 지표에서 유 의한 수준으로 나타났고, 공인타당도의 경우 단어수준에서 .91 -.98, 문장수준에서 .70-.93의 유의미한 상관을 보여 높은 타당 도를 보인 것으로 보고되었다(Kim et al., 2018). 이 외에 Kim et al.(2018)은 2;6-2;11세, 3, 4, 5, 6, 7세의 6개 집단에 대한 연령에 따른 발달적 타당도가 연령에 따라 단어와 문장 수준의 자음정 확도에서 유의한 차이가 있는 것으로 보고한 바 있다.

\section{6. 신뢰도 분석}

전라 지역 대상자 159 명 중 각 연령집단에서 2 명씩, 총 16 명 을 무작위로 선정하였다. 본 연구에 참여한 대학원생 1 명이 16 명의 음성파일을 모두 다시 들은 후, 아동의 반응을 정조음과 오조음으로 기록하였다. 표준화 작업에 참여한 다른 전사자들 의 기록과 해당 대학원생의 기록을 비교하여, 같은 항목에 대해 동일하게 기록된 경우는 ‘+’로, 그렇지 않은 경우는 ‘-’로 표시 하였다. 이와 같은 방법으로 검사자 간 신뢰도를 측정한 결과, 전체 문항 540개 중 ‘+’가 519개였으며 이를 백분율로 계산했을 때 신뢰도는 $96.12 \%$ 인 것으로 나타났다.

\section{7. 자료처리방법}

지역별 및 연령별 말소리산출 능력을 비교하기 위해 이원변 량분석(two-way ANOVA)을 실시하였다. 지역 또는 연령의 주 효과가 유의할 경우 Scheffé 검정을, 지역과 연령의 상호작용효 과가 유의할 경우 COMPARE syntax를 입력하여 사후검정을 실 시하였다. 이때 다중비교로 인한 1종 오류의 가능성을 줄이기 위해 Bonferroni 조정을 실시하였다. 통계처리는 SPSSWIN 23.0 프로그램을 사용하여 분석하였다.

\section{3. 연구 결과}

3.1. 지역 및 연령집단 별 $\mathrm{PWC}$ 비교

연령이 높아질수록 평균 PWC가 증가하여 6세에 이르면 .98 로 만점인 1.00 에 거의 가까워짐을 알 수 있다. 지역별로는 경상 도가 2세 후반에서 다른 지역보다 평균적으로 낮은 점수를 보 였다(표3).

표 3. 지역 및 연령별 $\mathrm{PWC}$ 기술통계 결과

Table 3. Descriptive Statistic Results of PWC by region and age

\begin{tabular}{|c|c|c|c|c|c|c|c|c|c|c|}
\hline Reg & & $\begin{array}{l}2 ; 6- \\
2 ; 11\end{array}$ & $\begin{array}{c}3 ; 0- \\
3 ; 5\end{array}$ & $\begin{array}{l}3 ; 6- \\
3 ; 11\end{array}$ & $\begin{array}{r}4 ; 0- \\
4 ; 5\end{array}$ & $\begin{array}{l}4 ; 6- \\
4 ; 11\end{array}$ & $\begin{array}{l}5 ; 0- \\
5 ; 11\end{array}$ & $\begin{array}{l}6 ; 0- \\
6 ; 11\end{array}$ & $\begin{array}{l}7 ; 0- \\
7 ; 11\end{array}$ & Total \\
\hline \multirow{3}{*}{ JL } & $\mathrm{M}$ & .48 & .48 & .75 & .76 & .74 & .94 & .98 & 1.00 & .76 \\
\hline & SD & .25 & .22 & .23 & .19 & .20 & .10 & .04 & .00 & .25 \\
\hline & $\mathrm{N}$ & 21 & 18 & 16 & 23 & 18 & 42 & 12 & 8 & 158 \\
\hline \multirow{3}{*}{ SG } & $\mathrm{M}$ & .55 & .65 & .68 & .77 & .81 & .94 & .99 & .99 & .84 \\
\hline & SD & .24 & .20 & .20 & .17 & .22 & .08 & .03 & .02 & .21 \\
\hline & $\mathrm{N}$ & 13 & 16 & 13 & 19 & 19 & 37 & 32 & 17 & 166 \\
\hline \multirow{3}{*}{ GS } & $\mathrm{M}$ & .39 & .55 & .83 & .80 & .87 & .92 & .98 & .99 & .81 \\
\hline & $\mathrm{SD}$ & .16 & .15 & .12 & .21 & .14 & .07 & .03 & .02 & .22 \\
\hline & $\mathrm{N}$ & 13 & 16 & 13 & 19 & 27 & 24 & 19 & 15 & 146 \\
\hline \multirow{3}{*}{$\mathrm{CC}$} & $\mathrm{M}$ & .44 & .47 & .63 & .79 & .79 & .94 & .98 & .99 & .79 \\
\hline & SD & .25 & .26 & .23 & .17 & .17 & .10 & .03 & .03 & .26 \\
\hline & $\mathrm{N}$ & 18 & 13 & 11 & 18 & 17 & 30 & 30 & 12 & 149 \\
\hline \multirow{3}{*}{ Total } & $\mathrm{M}$ & .46 & .54 & .73 & .78 & .81 & .94 & .98 & .99 & .80 \\
\hline & \begin{tabular}{|l|} 
SD \\
\end{tabular} & .23 & .22 & .21 & .18 & .18 & .09 & .03 & .02 & .24 \\
\hline & $\mathrm{N}$ & 65 & 61 & 61 & 81 & 72 & 134 & 93 & 52 & 619 \\
\hline
\end{tabular}

PWC, proportion of whole-word correctness; JL, Jeolla; SG, Seoul \& Gyeonggi; GS, Gyeongsang; CC, Chungcheong.

이원변량분석 결과(표 4), 지역별 차이가 유의하지 않았으나 $(F=2.463, p>.05)$, 연령별 차이 $(F=109.246, p<.001)$ 와 지역 및 연 령의 상호작용효과 $(F=1.667, p<.05)$ 가 유의하였다. 연령별 차이 에 대한 사후검정 결과, 2 세 후반과 3 세 초반은 이후 연령집단 모두와, 그리고 3 세 후반, 4세 초반 및 4세 후반은 5, 6, 7세 연령 집단과 각각 유의한 차이를 보였다 $(p<.001)$. 따라서 $\mathrm{PWC}$ 는 2 세 후반부터 5세까지 지속적으로 발달하는 말소리 능력 지표임을 알 수 있다. 상호작용효과에 대한 사후검정 결과, 2 세 후반에서 는 경상도가 서울경기보다, 3 세 초반에서는 전라도와 충청도가 서울경기보다 $\mathrm{PWC}$ 가 유의하게 낮았다( $p<.05)$. 
표 4. 지역별 및 연령별 $\mathrm{PWC}$ 이원변량분석 결과

Table 4. Two-way ANOVA results of PWC by region and age

\begin{tabular}{|c|c|c|c|c|c|c|}
\hline Source & $\begin{array}{l}\text { Type III } \\
\text { Sum of } \\
\text { Squares }\end{array}$ & $\mathrm{df}$ & $\begin{array}{c}\mathrm{M} \\
\text { Square }\end{array}$ & $\mathrm{F}$ & Sig. & Post-hoc \\
\hline $\begin{array}{c}\text { Corrected } \\
\text { Model } \\
\end{array}$ & 20.467(a) & 31 & .660 & 27.379 & .000 & \\
\hline Intercept & 326.239 & 1 & 326.239 & $13,528.683$ & .000 & \\
\hline Region & .178 & 3 & .059 & 2.463 & .062 & \\
\hline Age & 18.441 & 7 & 2.634 & $109.246^{* * *}$ & .000 & $\begin{array}{c}{ }^{* * *} \mathrm{~A}, \mathrm{~B}< \\
\mathrm{C}, \mathrm{D}, \mathrm{E}, \mathrm{F}, \\
\mathrm{G}, \mathrm{H} \\
{ }^{* * * *} \mathrm{C}, \mathrm{D}, \\
\mathrm{E}< \\
\mathrm{F}, \mathrm{G}, \mathrm{H} \\
\end{array}$ \\
\hline $\begin{array}{l}\text { Region } \times \\
\text { age }\end{array}$ & .844 & 21 & .040 & $1.667^{*}$ & .032 & $\begin{array}{c}\text { A: }{ }^{*} \\
\mathrm{GS}<\mathrm{SG} \\
\mathrm{B}:{ }^{*} \mathrm{JL}, \mathrm{CC} \\
<\mathrm{SG}\end{array}$ \\
\hline Error & 14.155 & 588 & .024 & & & \\
\hline Total & 433.379 & 620 & & & & \\
\hline $\begin{array}{c}\text { Corrected } \\
\text { total }\end{array}$ & 34.623 & 619 & & & & \\
\hline
\end{tabular}

$\mathrm{A}=2 ; 6-2 ; 11, \quad \mathrm{~B}=3 ; 0-3 ; 5, \quad \mathrm{C}=3 ; 6-3 ; 11, \quad \mathrm{D}=4 ; 0-4 ; 5, \quad \mathrm{E}=4 ; 6-4 ; 11$, $\mathrm{F}=5 ; 0-, \mathrm{G}=6 ; 0-6 ; 11, \mathrm{H}=7 ; 0-7 ; 11$.

${ }^{*} p<05,{ }^{* *} p<.01,{ }^{* * *} p<.001$.

PWC, proportion of whole-word correctness; JL, Jeolla; SG, Seoul \& Gyeonggi; GS, Gyeongsang; CC, Chungcheong.

\section{2. 지역 및 연령집단별 PMLU 비교}

연령이 증가할수록 평균 PMLU가 향상되었다. 지역별로는 경상도와 충청도가 2세 후반에서 다른 지역에 비해 평균 PMLU 가 상대적으로 낮았다(표 5).

표 5. 지역 및 연령별 PMLU 기술통계 결과

Table 5. Descriptive Statistic Results of PMLU by region and age

\begin{tabular}{|c|c|c|c|c|c|c|c|c|c|c|}
\hline Reg & & $\begin{array}{l}2 ; 6- \\
2 ; 11\end{array}$ & $\begin{array}{c}3 ; 0- \\
3 ; 5\end{array}$ & $\begin{array}{l}3 ; 6- \\
3 ; 11\end{array}$ & $\begin{array}{c}4 ; 0- \\
4 ; 5\end{array}$ & $\begin{array}{l}4 ; 6- \\
4 ; 11\end{array}$ & $\begin{array}{l}5 ; 0- \\
5 ; 11\end{array}$ & $\begin{array}{l}6 ; 0- \\
6 ; 11\end{array}$ & $\begin{array}{l}7 ; 0- \\
7 ; 11\end{array}$ & Total \\
\hline \multirow{3}{*}{$\mathrm{JL}$} & $\mathrm{M}$ & 7.34 & 7.44 & 8.10 & 8.13 & 8.14 & 8.49 & 8.53 & 8.57 & 8.09 \\
\hline & $\mathrm{SD}$ & .80 & .62 & .57 & .39 & .36 & .20 & .07 & .00 & .62 \\
\hline & $\mathrm{N}$ & 21 & 18 & 16 & 23 & 18 & 43 & 12 & 8 & 158 \\
\hline \multirow{3}{*}{ SG } & $\mathrm{M}$ & 7.67 & 8.01 & 8.01 & 8.18 & 7.87 & 8.47 & 8.54 & 8.55 & 8.25 \\
\hline & $\mathrm{SD}$ & .62 & .45 & .42 & .38 & 1.72 & .14 & .06 & .03 & .70 \\
\hline & $\mathrm{N}$ & 13 & 16 & 13 & 19 & 19 & 37 & 32 & 17 & 166 \\
\hline \multirow{3}{*}{ GS } & $\mathrm{M}$ & 7.15 & 7.66 & 8.30 & 8.22 & 8.34 & 8.45 & 8.55 & 8.56 & 8.21 \\
\hline & SD & .52 & .40 & .20 & .49 & .31 & .14 & .04 & .02 & .52 \\
\hline & $\mathrm{N}$ & 13 & 16 & 13 & 19 & 27 & 24 & 19 & 15 & 146 \\
\hline \multirow{3}{*}{$\mathrm{CC}$} & $\mathrm{M}$ & 7.19 & 7.41 & 7.89 & 8.20 & 8.21 & 8.48 & 8.58 & 8.55 & 8.15 \\
\hline & $\mathrm{SD}$ & .95 & .72 & .52 & .39 & .35 & .15 & .19 & .03 & .67 \\
\hline & $\mathrm{N}$ & 18 & 13 & 11 & 18 & 17 & 30 & 30 & 12 & 149 \\
\hline \multirow{3}{*}{$\begin{array}{c}\text { Tota } \\
1\end{array}$} & $\mathrm{M}$ & 7.33 & 7.63 & 8.08 & 8.18 & 8.16 & 8.48 & 8.55 & 8.56 & 8.17 \\
\hline & $\mathrm{SD}$ & .77 & .59 & .46 & .41 & .88 & .16 & .12 & .03 & .64 \\
\hline & $\mathrm{N}$ & 65 & 61 & 61 & 81 & 72 & 134 & 93 & 52 & 619 \\
\hline
\end{tabular}

PMLU, phonological mean length of utterance; JL, Jeolla; SG, Seoul \& Gyeonggi; GS, Gyeongsang; CC, Chungcheong.
이원변량분석 결과(표 6), 지역별 차이는 유의하지 않았으나 $(F=1.249, p>.05)$, 연령별 차이 $(F=54.882, p<.001)$ 와 지역과 연령 의 상호작용효과 $(F=1.667, p<.05)$ 는 유의하였다. 연령별 차이에 대한 사후검정 결과, 2 세 후반과 3 세 초반은 이후 연령집단 모 두와 3세 후반, 4세 초반 및 4세 후반은 5, 6, 7세 집단과 유의한 차이를 보였다 $(p<.001)$. 즉, PMLU 또한 2 세 후반부터 5 세까지 지속적으로 발달하는 말소리산출 지표임을 알 수 있다. 지역과 연령의 상호작용효과에 대한 사후검정 결과, 2 세 후반에서는 경상도가 서울경기보다, 3 세 초반에서는 전라도와 충청도가 서 울경기보다 수행력이 유의하게 낮음을 알 수 있었다 $(p<.05)$.

표 6. 지역 및 연령별 PMLU 이원변량분석 결과

Table 6. Two-way ANOVA results of PMLU by region and age

\begin{tabular}{|c|c|c|c|c|c|c|}
\hline Source & $\begin{array}{l}\text { Type III } \\
\text { Sum of } \\
\text { Squares }\end{array}$ & df & $\begin{array}{c}\text { M } \\
\text { Square }\end{array}$ & $\mathrm{F}$ & Sig. & Post-hoc \\
\hline $\begin{array}{c}\text { Corrected } \\
\text { Model }\end{array}$ & $108.470(\mathrm{a})$ & 31 & 3.499 & 14.533 & .000 & \\
\hline Intercept & $35,706.824$ & 1 & $35,706.824$ & $148,302.058$ & .000 & \\
\hline Region & .902 & 3 & .301 & 1.249 & .291 & \\
\hline Age & 92.498 & 7 & 13.214 & $54.882^{* * *}$ & .000 & $\begin{array}{l}{ }^{* * *} \mathrm{~A}, \mathrm{~B}<\mathrm{C}, \\
\mathrm{D}, \mathrm{E}, \mathrm{F}, \mathrm{G}, \mathrm{H} \\
{ }^{* * *} \mathrm{C}, \mathrm{D}, \\
\mathrm{E}<\mathrm{F}, \mathrm{G}, \mathrm{H}\end{array}$ \\
\hline $\begin{array}{l}\text { Region } \\
\text { age }\end{array}$ & 8.999 & 21 & .429 & $1.780^{*}$ & .018 & $\begin{array}{c}\mathrm{A}:{ }^{*} \\
\mathrm{GS}<\mathrm{SG} \\
\mathrm{B}:{ }^{*} \mathrm{JL}, \\
\mathrm{CC}< \\
\mathrm{SG}\end{array}$ \\
\hline Error & 141.573 & 588 & .241 & & & \\
\hline Total & $41,684.704$ & 620 & & & & \\
\hline $\begin{array}{c}\text { Corrected } \\
\text { total }\end{array}$ & 250.043 & 619 & & & & \\
\hline
\end{tabular}

$\mathrm{A}=2 ; 6-2 ; 11, \quad \mathrm{~B}=3 ; 0-3 ; 5, \quad \mathrm{C}=3 ; 6-3 ; 11, \quad \mathrm{D}=4 ; 0-4 ; 5, \quad \mathrm{E}=4 ; 6-4 ; 11$, $\mathrm{F}=5 ; 0-, \mathrm{G}=6 ; 0-6 ; 11, \mathrm{H}=7 ; 0-7 ; 11$.

${ }^{*} p<05,{ }^{* *} p<.01,{ }^{* * *} p<.001$.

PMLU, phonological mean length of utterance; JL, Jeolla; SG, Seoul \& Gyeonggi; GS, Gyeongsang; CC, Chungcheong.

3.3. 지역 및 연령집단별 PWP 비교

연령이 높아지면서 평균 PWP 또한 향상되었다. 2세 후반에 서는 서울경기 지역이 다른 지역보다 평균적으로 높았으나, 4 세 초반부터는 지역별 큰 차이가 없음을 알 수 있다(표 7).

이원변량분석 결과(표 8). 지역에 따른 차이 $(F=4.036, p<.01)$, 연령에 따른 차이 $(F=86.368, p<.001)$ 및 지역과 연령의 상호작용 효과 $(F=.083, p<.01)$ 가 모두 유의하였다. 지역에 대한 사후검정 결과 연령에 상관없이 전라도가 서울경기보다 수행력이 유의 하게 떨어지는 것으로 나타났다( $p<.01)$. 연령에 대한 사후검정 결과 2세 후반과 3 세 초반은 이후 연령집단 모두와, 3 세 후반, 4 세 초반, 4세 후반은 5, 6, 7세와 유의한 차이를 보였다( $p<.05)$. 지역과 연령에 대한 사후검정결과, 2 세 후반에서는 경상도가 서울경기보다, 3 세 초반에서는 전라도와 충청도가 서울경기보 다수행력이 유의하게 떨어졌다 $(p<.05)$. 
표 7. 지역과 연령집단별 PWP 기술통계 결과

Table 7. Descriptive Statistic Results of PWP by region and age

\begin{tabular}{|c|c|c|c|c|c|c|c|c|c|c|}
\hline Reg & & $\begin{array}{l}2 ; 6- \\
2 ; 11 \\
\end{array}$ & $\begin{array}{c}3 ; 0- \\
3 ; 5\end{array}$ & $\begin{array}{l}3 ; 6- \\
3 ; 11 \\
\end{array}$ & $\begin{array}{c}4 ; 0- \\
4 ; 5 \\
\end{array}$ & $\begin{array}{l}4 ; 6- \\
4 ; 11\end{array}$ & \begin{tabular}{|l|}
$5 ; 0-$ \\
$5 ; 11$
\end{tabular} & $\begin{array}{l}6 ; 0- \\
6 ; 11 \\
\end{array}$ & $\begin{array}{l}7 ; 0- \\
7 ; 11 \\
\end{array}$ & Total \\
\hline \multirow{3}{*}{ JL } & M & .86 & .87 & .95 & .95 & .95 & .99 & .99 & 1.00 & .94 \\
\hline & SD & 09 & 0 & 07 & 05 & 04 & 02 & 01 & .00 & .07 \\
\hline & $\mathrm{N}$ & 21 & 18 & 6 & 23 & 18 & 43 & 12 & 8 & 159 \\
\hline \multirow{3}{*}{ SG } & M & .90 & 93 & .94 & .95 & 96 & .99 & 1.00 & 1.00 & 96 \\
\hline & SD & .07 & .05 & .05 & .04 & .04 & .02 & .01 & .00 & .04 \\
\hline & $\mathrm{N}$ & 13 & & 13 & 19 & 1 & 37 & 32 & 17 & 166 \\
\hline \multirow{3}{*}{ GS } & $\mathrm{M}$ & .83 & 89 & .97 & .96 & .97 & .99 & 1.00 & 1.00 & .96 \\
\hline & SD & .06 & .05 & .02 & .06 & .04 & .02 & .01 & .00 & .06 \\
\hline & $\mathrm{N}$ & 13 & 16 & 13 & 19 & 27 & 24 & 19 & 15 & 146 \\
\hline & $\mathrm{M}$ & .84 & .8 & .92 & .96 & .96 & .99 & 1.00 & 1.00 & .95 \\
\hline & SD & .11 & .08 & .06 & .05 & .04 & .02 & .01 & .00 & .08 \\
\hline & $\mathrm{N}$ & 18 & 13 & 11 & 18 & 17 & 30 & 30 & 12 & 149 \\
\hline \multirow{3}{*}{$\begin{array}{c}\text { Tot } \\
\text { al }\end{array}$} & $\mathrm{M}$ & .85 & .89 & .94 & .95 & .96 & .99 & 1.00 & 1.00 & 1.11 \\
\hline & SD & .09 & .07 & .05 & .05 & .05 & .02 & .01 & .00 & 3.89 \\
\hline & $\mathrm{N}$ & 65 & 61 & 61 & 81 & 72 & 134 & 93 & 52 & 619 \\
\hline
\end{tabular}

PWP, proportion of whole-word proximity; JL, Jeolla; SG, Seoul \& Gyeonggi; GS, Gyeongsang; CC, Chungcheong.

표 8. 지역 및 연령집단별 PWP 이원변량분석 결과

Table 8. Two-way ANOVA results of PWP by region and age group

\begin{tabular}{c|c|c|c|c|c|c}
\hline Source & $\begin{array}{c}\text { Type III } \\
\text { Sum of } \\
\text { Squares }\end{array}$ & df & $\begin{array}{c}\text { M } \\
\text { Square }\end{array}$ & F & Siq & Post-hoc \\
\hline $\begin{array}{c}\text { Corrected } \\
\text { Model }\end{array}$ & $\begin{array}{c}1.446 \\
\text { (a) }\end{array}$ & 31 & .047 & 22.368 & .00 & \\
\hline $\begin{array}{c}\text { Intercept } \\
487.005\end{array}$ & 1 & 487.005 & $233,569.493$ & .00 & \\
\hline Region & .025 & 3 & .008 & 4.036 & .00 & ${ }^{* *} \mathrm{JL}<\mathrm{SG}$ \\
\hline $\begin{array}{c}\text { Age } \\
1.261\end{array}$ & 7 & .180 & 86.368 & .00 & ${ }^{*} \mathrm{~B}<\mathrm{C}, \mathrm{D}, \mathrm{E}, \mathrm{F}$, \\
$\mathrm{G}, \mathrm{H}$
\end{tabular}

3.4. 지역 및 연령집단별 Total PCC 와 UTAP PCC 결과 연령이 높아질수록 평균 Total PCC와 UTAP PCC가 향상되었 다(표 9, 표 10). Total PCC와 UTAP PCC 모두 2세 후반에서는 서 울경기 지역이 다른 지역들보다 월등히 높았으나, 3 세 초반을 지나 3 세 후반에 이르면 지역별 차이가 나타나지 않았다.
표 9. 지역과 연령집단별 Total PCC 기술통계 결과 Table 9. Descriptive Statistic Results of Total PCC by region and age group

\begin{tabular}{|c|c|c|c|c|c|c|c|c|c|c|}
\hline Reg & & $\begin{array}{l}2 ; 6- \\
2 ; 11\end{array}$ & $\begin{array}{c}3 ; 0- \\
3 ; 5\end{array}$ & $\begin{array}{l}3 ; 6- \\
3 ; 11 \\
\end{array}$ & $\begin{array}{c}4 ; 0- \\
4 ; 5\end{array}$ & $\begin{array}{l}4 ; 6- \\
4 ; 11\end{array}$ & $\begin{array}{l}5 ; 0- \\
5 ; 11\end{array}$ & $\begin{array}{l}6 ; 0- \\
6 ; 11 \\
\end{array}$ & $\begin{array}{l}7 ; 0- \\
7 ; 11 \\
\end{array}$ & Total \\
\hline \multirow{3}{*}{ JL } & $\mathrm{M}$ & 73.75 & 74.47 & 89.29 & 89.92 & 89.48 & 97.87 & 99.11 & 100.00 & 89.27 \\
\hline & $\mathrm{SD}$ & 15.82 & 12.93 & 11.98 & 8.45 & 8.95 & 3.71 & 1.56 & .00 & 13.27 \\
\hline & $\mathrm{N}$ & 21 & 18 & 16 & 23 & 18 & 43 & 12 & 8 & 159 \\
\hline \multirow{3}{*}{ SG } & $\mathrm{M}$ & 80.69 & 85.56 & 88.00 & 90.93 & 92.94 & 97.93 & 99.50 & 99.56 & 93.71 \\
\hline & $\mathrm{SD}$ & 12.52 & 9.83 & 9.22 & 8.41 & 9.63 & 2.83 & 1.15 & .76 & 9.14 \\
\hline & $\mathrm{N}$ & 13 & 16 & 13 & 19 & 19 & 37 & 32 & 17 & 166 \\
\hline \multirow{3}{*}{ GS } & $\mathrm{M}$ & 69.80 & 79.39 & 93.45 & 91.71 & 94.80 & 97.34 & 99.44 & 99.79 & 91.90 \\
\hline & $\mathrm{SD}$ & 9.62 & 9.75 & 4.77 & 10.34 & 6.75 & 2.49 & 1.14 & .60 & 11.12 \\
\hline & $\mathrm{N}$ & 13 & 16 & 13 & 19 & 27 & 24 & 19 & 15 & 146 \\
\hline \multirow{3}{*}{$\mathrm{CC}$} & $\mathrm{M}$ & 71.33 & 72.79 & 84.24 & 91.49 & 91.36 & 97.87 & 99.38 & 99.56 & 90.33 \\
\hline & $\mathrm{SD}$ & 18.10 & 16.37 & 10.85 & 6.92 & 8.13 & 3.46 & 1.05 & .84 & 13.87 \\
\hline & $\mathrm{N}$ & 18 & 13 & 11 & 18 & 17 & 30 & 29 & 12 & 148 \\
\hline \multirow{3}{*}{ Total } & $\mathrm{M}$ & 73.68 & 78.19 & 88.95 & 90.95 & 92.46 & 97.79 & 99.40 & 99.69 & 91.34 \\
\hline & SD & 15.05 & 12.98 & 9.95 & 8.49 & 8.37 & 3.20 & 1.16 & .68 & 12.04 \\
\hline & $\mathrm{N}$ & 65 & 61 & 61 & 81 & 72 & 134 & 93 & 52 & 619 \\
\hline
\end{tabular}

PCC, percentage of consonants correct; JL, Jeolla; SG, Seoul \& Gyeonggi; GS, Gyeongsang; CC, Chungcheong.

표 10. 지역과 연령집단별 UTAP PCC 기술통계 결과

Table 10. Descriptive Statistic Results of UTAP PCC by region and age

\begin{tabular}{|c|c|c|c|c|c|c|c|c|c|c|}
\hline Reg & & $\begin{array}{l}2 ; 6- \\
2 ; 11\end{array}$ & $\begin{array}{c}3 ; 0- \\
3 ; 5\end{array}$ & $\begin{array}{l}3 ; 6- \\
3 ; 11\end{array}$ & $\begin{array}{c}4 ; 0- \\
4 ; 5\end{array}$ & $\begin{array}{l}4 ; 6- \\
4 ; 11\end{array}$ & $\begin{array}{l}5 ; 0- \\
5 ; 11\end{array}$ & $\begin{array}{l}6 ; 0- \\
6 ; 11 \\
\end{array}$ & $\begin{array}{l}7 ; 0- \\
7 ; 11\end{array}$ & Total \\
\hline \multirow{3}{*}{$\mathrm{JL}$} & $\mathrm{M}$ & 74.80 & 75.11 & 90.11 & 89.58 & 89.81 & 98.06 & 99.13 & 100.00 & 89.61 \\
\hline & SD & 16.47 & 11.29 & 10.42 & 9.46 & 9.29 & 3.65 & 1.88 & .00 & 12.99 \\
\hline & $\mathrm{N}$ & 21 & 18 & 16 & 23 & 18 & 43 & 12 & 8 & 159 \\
\hline \multirow{3}{*}{ SG } & $\mathrm{M}$ & 81.25 & 83.59 & 86.86 & 91.01 & 92.64 & 98.14 & 99.61 & 99.76 & 93.54 \\
\hline & SD & 11.97 & 9.83 & 9.82 & 7.67 & 9.97 & 2.59 & 1.23 & .69 & 9.33 \\
\hline & $\mathrm{N}$ & 13 & 16 & 13 & 19 & 19 & 37 & 32 & 17 & 166 \\
\hline \multirow{3}{*}{ GS } & $\mathrm{M}$ & 73.72 & 82.03 & 94.71 & 92.00 & 95.29 & 98.09 & 99.78 & 99.58 & 92.92 \\
\hline & $\mathrm{SD}$ & 7.58 & 8.40 & 4.78 & 9.60 & 6.19 & 2.67 & .96 & 1.17 & 9.82 \\
\hline & $\mathrm{N}$ & 13 & 16 & 13 & 19 & 27 & 24 & 19 & 15 & 146 \\
\hline \multirow{4}{*}{$\mathrm{CC}$} & $\mathrm{M}$ & 71.87 & 73.40 & 84.09 & 92.13 & 92.03 & 97.50 & 99.38 & 99.31 & 90.56 \\
\hline & SD & 16.75 & 17.06 & 12.47 & 6.09 & 8.66 & 4.11 & 1.24 & 1.36 & 13.64 \\
\hline & $\mathrm{N}$ & 18 & 13 & 11 & 18 & 17 & 30 & 30 & 12 & 149 \\
\hline & $\mathrm{M}$ & 75.06 & 78.67 & 89.19 & 91.09 & 92.77 & 97.96 & 99.51 & 99.64 & 91.67 \\
\hline
\end{tabular}

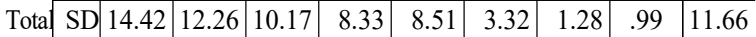

\begin{tabular}{|l|l|l|l|l|l|l|l|l|l|l|}
\hline $\mathrm{N}$ & 65 & 61 & 61 & 81 & 72 & 134 & 93 & 52 & 619 \\
\hline
\end{tabular}

UTAP, urimal test of articulation and phonology; PCC, percentage of consonants correct; JL, Jeolla; SG, Seoul \& Gyeonggi; GS, Gyeongsang; CC, Chungcheong.

Total PCC에 대한 이원변량분석 결과, 지역별 차이 $(F=4.69$, $p<.01)$, 연령별 차이 $(F=93.504, p<.001)$, 지역과 연령의 상호작용 효과 $(F=1.912, p<.01)$ 가 모두 유의하였다. 지역에 대한 사후검정 결과 전라도와 충청도가 서울경기보다 수행력이 유의하게 떨 어졌다 $(p<.05)$. 연령에 대한 사후검정 결과, 2 세 후반과 3 세 초 반은 이후 연령집단 모두와, 3 세 후반, 4 세 초반, 4 세 후반은 5 , $6,7$ 세와 유의한 차이를 보였다( $p<.05)$. 지역과 연령의 상호작용 효과에 대한 사후검정결과, 2 세 후반에서는 경상도와 충청도가 서울경기보다, 3 세 초반에서는 전라도와 충청도가 서울경기보 다 $\mathrm{PCC}$ 가 유의하게 떨어졌다 $(p<.05$; 그림 1$)$. 
Total PCC

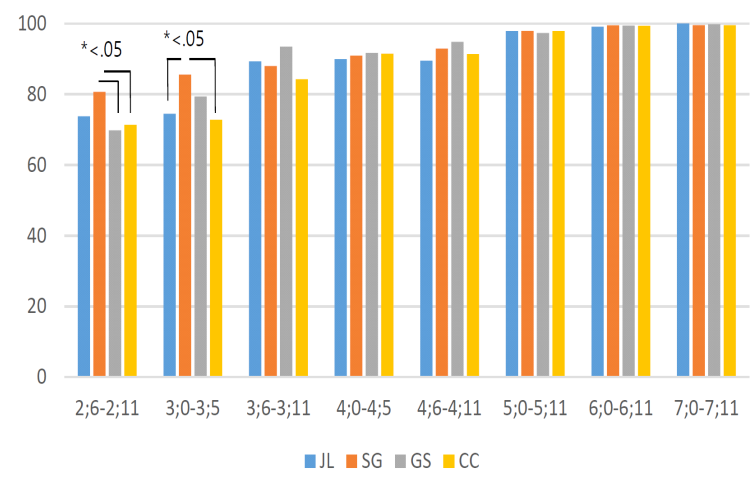

그림 1. 지역 및 연령별 Total PCC

Figure 1. Total PCC by region and age

PCC, percentage of consonants correct; JL, Jeolla; SG, Seoul \&

Gyeonggi; GS, Gyeongsang; CC, Chungcheong.

UTAP PCC에 대한 이원변량분석 결과도 Total PCC와 거의 유사하였다. 전라도와 충청도가 서울경기보다 수행력이 유의 하게 떨어졌고, 2 세 후반과 3 세 초반은 4세 초반 이후 연령들과, 3 세 후반, 4 세 초반, 4 세 후반은 5 세 이후 연령들과 유의한 차이 를 보였다 $(p<.05)$. 지역과 연령에 대한 사후검정결과, 2 세 후반 에서는 충청도가 서울경기보다, 3 세 초반에서는 전라도와 충청 도가 서울경기보다 $\mathrm{PCC}$ 가 유의하게 떨어졌다 $(p<.05$; 그림 2).

\section{UTAP PCC}

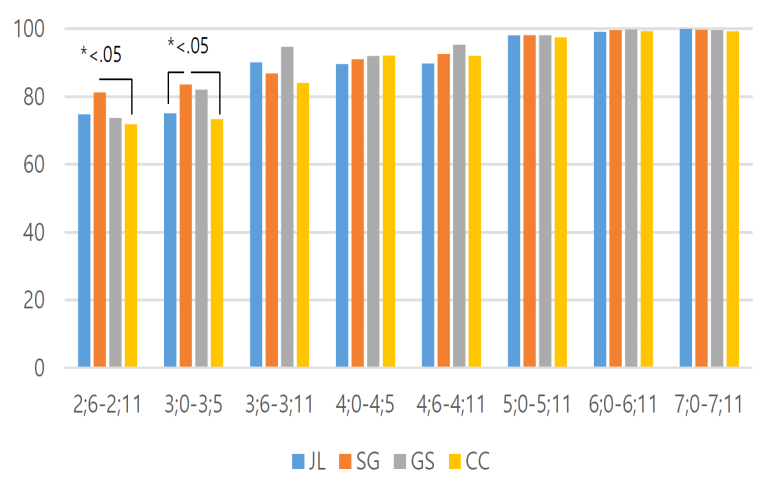

그림 2. 지역 및 연령별 UTAP PCC

Figure 2. UTAP PCC by region and age

UTAP, urimal test of articulation and phonology; PCC, percentage of consonants correct.

\section{4. 논의 및 결론}

언어치료 임상에서는 아동의 말소리 발달에 대한 기준이 매 우 중요하며 여기에 영향을 줄 수 있는 요인들 역시 고려해야 한다. 말소리 발달에 영향을 미치는 변인으로는 나이, 성별, 지 능 등뿐 아니라 개인적인 차이를 들 수 있는데, 여기에 부모의 사회·경제적 위치(SES), 언어 발달(형태론적이고 통사적인 부 분) 등을 포함하기도 한다(Owens, 2012). 이에 더해 지역별 차이
에 대한 연구는 많지 않으나 방언이나 지역의 특성에 따라 아동 말소리 발달에 영향을 줄 수 있으므로 이에 대한 자료가 필요하 다. 말소리에 대한 완전한 습득이 이루어지기 전에는 지역별로 어느 정도 발달 양상에 차이가 있을 것으로 예상된다. 따라서 본 연구에서 말소리 발달에 지역별 말소리 차이가 실제로 존재 하는지 살펴보기 위해, 전라, 서울경기, 충청, 경상 지역 아동들 의 말소리 산출 능력을 비교하였다.

본 연구가 지역 및 연령에 따른 말소리산출 능력을 비교한 것 인 만큼, 지역과 연령의 상호작용 효과에 대한 결과를 중심으로 정리해 보면 다음과 같다. 첫째, 단어단위 지표인 PWC, PMLU, PWP에서는, 2세 후반의 경우 경상도 지역이, 그리고 3세 초반 의 경우 전라도와 충청도 지역이 서울경기 지역보다 수행력이 유의하게 떨어졌다. 그러나 3 세 후반부터는 어떤 지표에서도 지역 간 차이가 관찰되지 않았다. 둘째, 분절음 차원의 지표인 $\mathrm{PCC}$ 에 대해서는, 2 세 후반의 경우 Total PCC에서 경상도와 충 청도가, UTAP PCC에서 충청도가 서울경기 지역보다 수행력이 유의하게 떨어졌고, 3세 초반의 경우 두 지표 모두에서 전라도 와 충청도가 서울경기보다 수행력이 유의하게 떨어졌다. 그러 나, 단어단위 지표와 마찬가지로, 3 세 후반부터는 Total PCC와 UTAP PCC 모두에서 지역 간 차이가 나타나지 않았다.

이와 같은 결과는 어린 연령의 경우 말소리산출 능력에 국내 의 지역 간 차이가 분명히 존재하며, 그 차이가 서울과 지방의 차이로 설명될 수 있음을 시사한다. 따라서 국내의 경우 지역 간 차이가 방언의 차이라기보다, ‘수도권’과 ‘지방’이라는 용어 에 함축되어 있는 교육, 문화, 사회경제적 요인 등의 차이로 인 해 초래된 결과일 가능성을 고려해 보아야 할 것이다. 그러나 그 보다 더 주목해야 할 점은 그 차이가 단지 2세 후반과 3 세 초 반이라는 어린 연령에만 국한되었을 뿐, 3 세 후반 이후의 연령 에서는 어떤 지표에 대해서도 지역 간 차이가 나타나지 않았다 는 것이다. 즉, 3 세 후반을 거치면서 수행력이 떨어졌던 전라도, 충청도, 경상도 지역의 아동들 모두 서울경기 지역의 아동들만 큼 말소리산출 능력이 향상되어, 5 세에 이르러서는 모든 지역 이 아동들이 말소리습득의 안정기에 들어선다는 것을 알 수 있 다. 이러한 결과에 대한 이유로 대중매체, 교육기관의 영향 등 을 고려해볼 수 있으나, 이에 대해서는 후속 연구에서 보다 자 세히 다루어 보아야 할 것이다.

본 연구는 그 동안 국내에서 연구된 바가 없는 전국 규모 단 위의 아동들을 대상으로 지역 간 말소리 발달의 차이를 비교하 고, 어린 연령대와 이후 연령대에서 그 차이가 다소 상이하게 나타난다는 것을 밝혔다는 점에서 의의가 있다. 그러나 본 연구 는 국내에 거주하는 단일언어 사용 아동들로 대상자를 한정하 였고, 점진적으로 증가하고 있는 다문화권 아동들을 포함하지 는 않았다. 다문화권 아동들이 지방에 보다 많이 거주한다는 점 을 고려할 때, 이러한 차이 또한 지역별 차이를 초래하는 요인 일 가능성을 생각해볼 수 있다. Hwang \& Kim(2015)에서도 베트 남 다문화 아동은 동화변동이 더 많이 일어난다는 연구결과를 보여 주었다. 따라서 지역 간 차이를 유발하는 더 많은 변수들 을 포함하여 그 변수 각각이 말소리 발달에 미치는 영향에 대해 
살펴보는 보다 심층적인 후속연구가 요구된다. 또한 한 부모 가 정의 아이들에서는 언어발달이나 말소리 발달이 다를 수 있다 는 견해도 있어(Owens, 2012) 말소리 산출에 여러 요인이 관여 할 수 있음을 고려해야 한다.

Owens(2012)에 의하면 음소발달에는 개인차가 상당히 존재 하며, 일부 말소리의 습득 연령은 3 세까지 유동적일 수 있다. 본 연구에서도 3 세까지는 지역 간 차이가 있었으나 그 이후에는 지역 간 차이가 관찰되지 않았다. 특정 연령대에서 지역별 차이 가 존재하는 것이 확인된 만큼, 말소리산출 능력 평가 시 지역 을 포함한 기타 요인들에 대한 고려가 반드시 필요할 것이다. 더불어 지역별 방언 특성으로 인해 해당 아동의 말소리가 표준 자료와 차이를 보인다면, 이 경우 또한 말소리오류 또는 말소리 장애와는 구별되어야 할 것이다. 이는 말소리산출 능력에 대한 평가결과를 해석할 때에는 반드시 개인차를 고려해야 하며, 어 린 연령대 아동의 경우 더욱 그러하다는 것을 시사한다.

\section{References}

Cheon, H. J., \& Lee, S. H. (1999). The development of Korean /s/ (/入/) and $/ \mathrm{s}^{\prime} /(/$ 从/) in normal children of ages 2-7 years, Communication Science and Disorders, 4(1), 1-24.

Choi, M. S., \& Kim, S. J. (2013). Morphological influences on liquid acquisition in Korean children's spontaneous speech, Communication Sciences and Disorders, 18(1), 76-85.

Davis, B. L., \& Bedore, L. M. (2011). Developmental speech disorders, In R. B. Gillam, T. P. Marquardt, \& F. N. Martin. (Eds.), Communication sciences and disorders: From science to clinical practice. Sudbury, MA: Jones and Bartllett, LLC.

Dodd, B., Holm A., Hua Z., \& Crosbie, S. (2003). Phonological development: A normative study of British English-speaking children, Clinical Linguistics and Phonetics, 17(8), 617-643.

Ha, J. W., Kim, S. J., Kim, Y. T., \& Shin, M. (2019). Developmental analysis in Korean children's speech production using percentage of consonants correct and whole-word measurements, Communication Sciences and Disorders, 24(2), 469-477.

Heo, S. R., \& Shin, M. S. (2016). Accuracy comparison of Korean $/ \mathrm{s} /$ and $/ \mathrm{s} * /$ in children aged 4 to 7 years depending on the vowel environments. Proceedings of the 2016 Conference on the Korean Speech-Language and Hearing Association (pp. 290-293).

Hwang, S. S., \& Kim, S. J. (2015). Phonological error patterns in children from culturally and linguistically diverse backgrounds compared to children with speech sound disorders, Communication Sciences and Disorders, 20(3), 456-468.

Jang, H. J. (2013). Generational differences of the fricatives in the Daegu dialect. Korean Linguistics, 58, 235-258.

Jeon, H. S., Shin, M. S., \& Kwon, D. D. (2002). The characteristics of Korean consonant / ᄅ/ development is reflected in phonemic situation, Journal of Speech-Language \& Hearing Disorders,
11(2), 205-218.

Kim, M. Y. (2012). The effectiveness of the whole-word approach on articulation and phonological ability of the children with Down syndrome (Master's thesis). Gwangju Women's University, Korea.

Kim, S. J., \& Shin, J. Y. (2015). Speech sound disorders. Seoul: Sigmapress.

Kim, S. J., Kim, J. M., Yoon, M. S., Chang, M. S., \& Cha, J E. (2012). Alveolar fricative sound errors by the type of morpheme in the spontaneous speech of 3- and 4-year-old children, Phonetics and Speech Sciences, 4(3), 129-136.

Kim, T. (1991). A study on geographical differentiations in Kyeongsangnam-do dialects (Doctoral dissertation). Kon-kuk University, Korea.

Kim, Y. J. (2014). Distinction aspect of / 入/ and / 从/ of Gyeongnam Changnyeong dialect, Urimal, 38, 73-98.

Kim, Y. T. (1996). The percentage of consonant correct (PCC) using picture articulation test in preschool children. Communication Sciences and Disorders, 1, 7-34.

Kim, Y. T., Park, H., Kang, J. K., Kim, J. A., Shin, M, Kim, S. J., \& Ha, J. W. (2018). Validity and reliability analyses for the development of Urimal Test of articulation and phonology-2, Communication Sciences and Disorders, 23(4), 959-970.

Kim, Y. T., \& Shin, M. J. (2004). Urimal test of articulation and phonology(U-TAP). Seoul: Haksisa.

Lanwermeyer, M., Henrich, K., Rocholl, M. J., Schnell, H. T., Werth, A., Herrgen, J., \& Schmidt, J. E. (2016). Dialect variation influences the phonological and lexical-semantic word processing in sentences. Electrophysiological evidence from a crossdialectal comprehension study, Frontiers in Psychology, 7, 1-18.

Lee, K. J., \& Choi, S. H. (2015). Lexical and articulation development of kindergarteners in Daegu area. Proceedings of the 4th Collaboration Conference on the Korean Academy of SpeechLanguage Pathology and Audiology \& the Korean Speechlanguage and Hearing Association (pp. 104-105). Daejeon, Korea.

Oum, J. (1986). Speech-sound development in children aged three to five years in Korean with special reference to consonants (Master's thesis). Ewha Womens University, Korea.

Owens, R. E. (2012). Language development: An introduction ( $8^{\text {th }}$ ed.). Boston, MA: Pearson.

Park, E. H., \& Yoon, M. S. (2016). Speech sound development of toddlers in spontaneous speech: Segmental level and whole word level analysis, Korean Journal of Early Childhood Special Education, 16(2), 111-130.

Seok, D. I. (2006). A whole-word approach to phonological analysis with normal children aged from 3 to 5 years, Journal of Speech \& Hearing Disorders, 15(1), 15-28. 
Shin, H. J., \& Lee, E. J. (2015). Phonological characteristics of late-talkers through phonological whole-word analysis, Communication Sciences and Disorders, 20(2), 157-165.

Smit, A. B., Hand, L. Freilinger, J. J., Bernthal, J. E., \& Bird, A. (1990). The lowa articulation norms project and its Nebraska replication, Journal of Speech and Hearing Disorders, 55(4), 779-798.

Yoon, M. S., Kim, J. M., \& Kim, S. J. (2013). Phonological whole-word measures of spontaneous speech in children two to four years of age, Journal of Speech \& Hearing Disorders, 22(4), 69-85.

\section{- 신문자 (Moonja Shin)}

조선대학교 언어치료학과 교수

광주광역시 동구 필문대로 309

Tel: 062-230-6187 Fax: 062-230-6271

Email: moonjashin@chosun.ac.kr

관심분야: 유창성장애, 조음음운장애

- 하지완 (Ji-Wan Ha) 교신저자

대구대학교 언어치료학과 교수

경상북도 경산시 진량읍 대구대로 201

Tel: 053-850-4327 Fax: 053-850-4329

Email: jw-ha@daegu.ac.kr

관심분야: 조음음운장애, 신경말-언어장애

\section{- 김영태 (Young Tae Kim)}

이화여자대학교 언어병리학과 교수 서울특별시 서대문구 이화여대길 52

Tel: 02-3277-2120 Fax: 02-3277-2122

Email: youngtae@ewha.ac.kr

관심분야: 언어발달장애, 조음음운장애

- 김수진 (Soo-Jin Kim)

나사렛대학교 언어치료학과 교수

충청남도 서북구 쌍용2동 456 번지

Tel: 041-570-7978 Fax: 041-570-7846

Email: sjkim@kornu.ac.kr

관심분야: 조음음운장애, 말장애 


\title{
우리나라 아동의 지역별 말소리 발달 차이
}

\author{
신 문 자 ${ }^{1} \cdot$ 하 지 완 ${ }^{2} \cdot$ 김 영 태 ${ }^{3}$ 김 수 진 ${ }^{4}$ \\ 1조선대학교 언어치료학과, ${ }^{2}$ 대구대학교 언어치료학과, \\ ${ }^{3}$ 이화여자대학교 언어병리학과, ${ }^{4}$ 나사렛대학교 언어치료학과
}

\begin{abstract}
국문초록
본 연구의 목적은 우리나라 아동들의 말소리산출 발달에 지역적 차이가 존재하는지를 알아보고자 하는 것이다. 2 세 후반부터 7 세에 해당하는 전라, 서울경기, 경상, 충청 지역의 아동 619 명이 본 연구에 참여하였고, 대상자들에게 우리말 조음음운평가 2 의 단어수준 검사를 진행하였다. 수집된 데이터에 대해 지역 및 연령에 따른 단어단위정확 률(PWC), 평균음운길이(PMLU), 단어단위근접률(PWP), 전체 자음정확도(Total PCC), UTAP 자음정확도(UTAP $\mathrm{PCC}$ )를 비교 분석하였다. 연구결과 단어단위 지표인 PWC, PMLU, PWP에서는, 2 세 후반의 경우 경상도 지역에서, 3 세 초반의 경우 전라도와 충청도 지역에서 서울경기 지역보다 수행력이 유의하게 낮았다. 그러나 3 세 후반부터는 어떤 단어단위 지표에서도 지역 간 차이가 관찰되지 않았다. 분절음 차원의 지표인 $\mathrm{PCC}$ 에서는, 2 세 후반의 경우 Total PCC에서 경상도와 충청도가, UTAP PCC에서 충청도가 서울경기 지역보다 수행력이 유의하게 떨어졌고, 3 세 초반의 경우 두 지표 모두에서 전라도와 충청도가 서울경기보다 수행력이 유의하게 떨어졌다. 그러나 3 세 후반부 터는 Total PCC와 UTAP PCC 모두에서 지역 간 차이가 나타나지 않았다. 이러한 결과는 어린 연령의 경우 말소리산 출 능력에 국내의 지역 간 차이가 존재하며, 그 차이가 특정 지역의 특성이라기보다는 서울과 지방의 차이로 설명 될 수 있음을 시사한다.
\end{abstract}

핵심어: 말소리 발달, 지역 차이, 우리말 조음음운평가2

\section{참고문헌}

김민영 (2012). 단어단위 접근법이 다운증후군아동의 조음음운 능력 개선에 미치는 효과. 광주여자대학교 석사학위논문.

김수진, 김정미, 윤미선, 장문수, 차재은 (2012). 자발화에 나타난 형태소 유형에 따른 3-4세 아동의 치경마찰음 오류. 말소리 와 음성과학, 4(3), 129-136.

김수진, 신지영 (2015). 말소리장애. 서울: 시그마프레스.

김영태 (1996). 그림자음검사를 이용한 취학전 아동의 자음정확 도 연구. 언어청각장애연구, 1, 7-34.

김영태, 박희영, 강진경, 김정아, 신문자, 김수진, 하지완(2018). 우리말 조음·음운평가-2(UTAP2) 개발을 위한 타당도 및 신뢰 도 분석. 언어청각장애연구, 23(4), 959-970.

김유정 (2014). 경남 창녕지역어의 / ㅅ/과 / ㅆ/의 변별 양상. 우리 말연구집, 38, 73-98.

김영태, 신문자 (2004). 우리말 조음음운평가. 서울: 학지사. 김택구 (1991). 경상남도 방언의 지리적 분화에 관한 연구. 건국대 학교 박사학위논문.

박은희, 윤미선 (2016). 자발화에 나타난 2 - 3세 유아의 말소리 발 달: 분절음과 단어 단위에서의 평가. 유아특수교육연구, $16(2)$,
111-130.

석동일 (2006). 단어단위 접근법에 의한 3 - 5세 유아의 음운특성 분석. 언어치료연구, 15(1), 15-28.

신화정, 이은주(2015). 단어단위 음운분석에 의한 말 늦은 아동의 음운 특성. 언어청각장애연구, 20(2), 157-165.

엄정희 (1986). 3, 4, 5 세 아동의 말소리 발달에 관한 연구. 자음을 중심으로 이화여자대학교 석사학위논문.

윤미선, 김정미, 김수진 (2013). 자발화 문맥에서의 단어단위 음 운 평가. 언어치료연구, 22(4), 69-85.

이경재, 최성희 (2015). 대구지역 유치원생의 어휘 및 조음 발달, 한국언어치료학회. 한국언어청각임상학회 2015 년도 제 4 회 공 동학술대회 발표논문집 (pp. 104-105). 대전: 우송대학교.

장혜진 (2013). 대구방언 마찰음의 세대 간 차이. 한국어학, 58 , 235-258.

전희정, 이승환 (1999). 2 - 7세 정상아동의 / ㅅ/와 / ㅆ/ 말소리 발 달 연구. 언어청각장애연구, 4(1), 1-24.

최민실, 김수진 (2013). 자발화에 나타난 3 - 4세 아동의 형태소 유 형별 유음 발달 특성. 언어청각장애연구, 18(1), 76-85.

하지완, 김수진, 김영태, 신문자 (2019). 자음정확도와 단어단위 음운지표를 이용한 일반아동의 말소리 산출능력에 대한 발달 
연구, 언어청각장애연구, 24(2), 469-477.

허승룡, 신명선 (2016). 4 - 7세 아동의 모음환경에 따른 / ㅅ/, / ㅆ/ 정확도 연구. 한국언어치료학회. 한국언어청각임상학회 2016 년도 제5회 공동학술대회 발표논문집(pp. 290-293).

황상심, 김수진 (2015), 베트남 다문화 아동과 말소리장애 아동의 음운오류패턴, 언어청각장애연구, 20(3), 456-468. 